\title{
Recursos contra los laudos arbitrales CIADI: ÚNICO EN SU GÉNERO
}

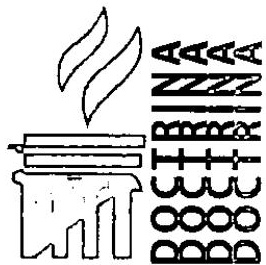

\section{Fernando Cantuarias Salaverry}

Abogado por la Pontificia Universidad Católica del Perú y Master en Derecho (LL.M.) por la Universidad de Yale.

Árbitro nacional e internacional.

Decano de la Facultad de Derecho de la Universidad Peruana de Ciencias Aplicadas. Miembro del Board of Reporters del Institute of Transnational Arbitration, del Grupo Latinoamericano de

Arbitraje de la Cámara de Comercio Internacional, del Comité Editor de la Revista Peruana de Arbitraje y del Comité Argentino de Arbitraje Nacional y Transnacional.

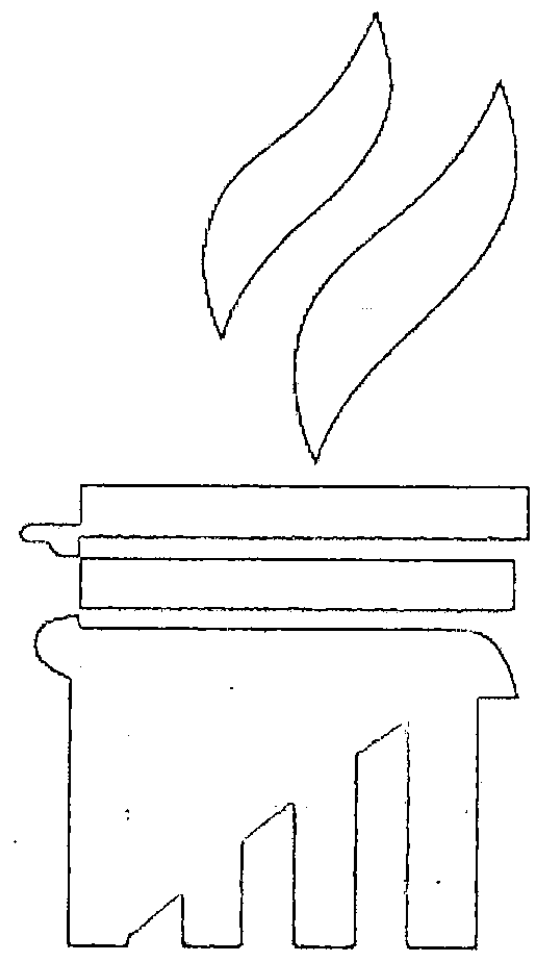

SUMARIO:

I. Recursos contra el laudo arbitral CIADI.

II. Recurso de suplementación y rectificación.

III. Recurso de aclaración.

IV. Recurso de revisión.

V. Recurso de anulación:

1. Cuestiones generales;

2. Autoridad que conoce del recurso y sus efectos;

3. Las causales de anulación. 
El Convenio sobre Arreglo de Diferencias Relativas a Inversiones entre Estados y Nacionales de otros Estados (CIADI o ICSID en sus siglas en inglés)' fue aprobado por el Banco Mundial en 1965 con la expresa finalidad de despolitizar la solución de los conflictos sobre inversiones mediante la utilización de la vía arbitral. Este acuerdo internacional entró en vigencia el 14 de octubre de $1966 .^{2}$

Esta Convención tuvo y tiene como misión principal la de crear un foro arbitral neutral ${ }^{3}$ que se encargue de resolver los conflictos re- feridos a inversiones entre Estados miembros y particulares de otros Estados miembros, con la finalidad de incentivar la inversión foránea en dichos países. En ese sentido, en el Reporte del Directorio Ejecutivo de la Convención se señala que "[I]a creación de una institución designada para facilitar la solución de disputas entre Estados e inversionistas de otros Estados puede significar un paso importante en la promoción de un ambiente de confianza mutua, estimulando así el crecimiento de la inversión privada internacional en aquellos Estados que deseen atraerla".

1 El texto del tratado se ubica en: http//icsid.worldbank.org/ICSID/StaticFiles/baiscdoc-spa/crr.spanish-final.pdf. Al 4 de noviembre de 2007, 143 Estados forman parte de este tratado, a saber: Afganistán, Albania, Alemania, Arabia Saudita, Argelia, Argentina, Armenia, Australia, Austria, Azerbaiyán, Bahamas, Bahrein, Bangladesh, Barbados, Belarús, Bélgica, Benin, Bosnia y Herzegovina, Botswana, Brunei Darussalam, Bulgaria, Burkina Faso, Burundi, Camboya, Camerún, Colombia, Comoras, Congo, Corea del Sur, Costa de Marfíl, Costa Rica, Croacia, Chad, Chile, China, Chipre, Dinamarca, Ecuador, Egipto, El Salvador, Emiratos Árabes Unidos, Eslovenia, España, Estados Unidos de América, Estonia, Fiji, Filipinas, Finlandia, Francia, Gabón, Gambia, Georgia, Ghana, Granada, Grecia, Guatemala, Guinea, Guyana, Honduras, Hungría, Indonesia, Irlanda, Islandia, Islas Salomón, Israel, Italia, Jamaica, Japón, Jordania, Kazajstán, Kenya, Kuwait, Lesotho, Letonia, Líbano, Liberia, Lituania, Luxemburgo, Macedonia, Madagascar, Malasia, Malawi, Mali, Malta, Marruecos, Mauricio, Mauritania, Micronesia, Mongolia, Mozambique, Nepal, Nicaragua, Niger, Nigeria, Noruega, Nueva Zelanda, Omán, Países Bajos, Pakistán, Panamá, Papua Nueva Guinea, Paraguay, el Perú, Portugal, Reino Unido de Gran Bretaña e Irlanda del Norte, República Centroafricana, República Checa, República Democrática de Congo, República del Yemen, República Eslovaca, Rumania, Rwanda, Saint Kitts y Nevis, San Vicente y las Granadinas, Samoa, Santa Lucía, Senegal, Serbia, Seychelles, Sierra Leona, Singapur, Siria, Somalia, Sri Lanka, Sudán, Suecia, Suiza, Swazilandia, Tanzania, Timor-Leste, Togo, Tonga, Trinidad y Tobago, Túnez, Turkmenistán, Turquia, Ucrania, Uganda, Uruguay, Uzbekistán, Venezuela, Zambia y Zimbabwe. Fuente: ICSID-List of Contracting States (www.worldbank.org/icsid). Bolivia denunció el Tratado en el año 2007. Sobre este particular, leer a: MANTILLASERRANO, Fernando, La denuncia de la Convención de Washington, ¿impide el recurso al CIADI? En: Revista Peruana de Arbitraje, No. 6, 2008, pp. 205-216.

2 Sobre los antecedentes de este tratado, leer a: BROCHES, Aron, The Convention on the Settlement of Investment Disputes: Some Observations on Jurisdiction. En: Columbia Journal of Transnational Law, Vol. 5, No. 2, 1966, pp. 263-280; AMERASINGHE, C.F., The International Centre for Settlement of Investment Disputes and Development through the Multinational Corporation. En: Vanderbilt Journal of Transnational Law, Vol. 9, 1976, pp. 793-816; y SCHREUER, Christoph, The ICSID Convention: A Commentary, Cambridge University Press, 2001, pp. 1-30.

3 EI CIADI también provee una instancia conciliatoria (del artículo 28 al 35 del Convenio CIADI), la cual no será analizada en este trabajo. Sobre el tema, leer a: NURICK, Lester y J. SCHNABLY, Stephen, The First ICSID Conciliation: Tesoro Petroleum Corporation v. Trinidad and Tobago. En: ICSID Review. Foreign Investment Law Journal, Vol. 1, 1986, pp. 340350; y, SCHREUER, Christoph, Commentary on the ICSID Convention, Article 25. En: ICSID Review. Foreign Investment Law Journal, Vol. 11, No. 2, 1996, pp. 334 y ss.

4 Traducción libre del autor, AMERASINGHE, C.F., The International Centre for Settlement of Investment Disputes and Development through the Multinational Corporation, Ob. Cit., p. 794. "The creation of an institution designed to facilitate the settlement of disputes between States and foreign investors can be a major step toward promoting an atmosphere of mutual confidence and thus stimulating a larger flow of private international capital into those countries which wish to attract it". M. MOORE, Michael, international Arbitration between States and Foreign Investors - The World Bank Convention. En: Stanford Law Review, Vol. 18, No. 6, 1966, p. 1375. "The World Bank Convention offers all countries wishing to increase the flow of private investment into their economies a flexible new instrument for their investment promotion policy". CHUKWUMERIJE, Okezie, International Law and Article 42 of the ICSID Convention. En: Journal of International Arbitration, Vol. 14, No. 3, 1997, pp. 79-80. "As an independent, non-State entity established by an international treaty, ICSID is expected to depoliticize the arbitration of State investment disputes. It purports to provide a neutral forum in 
Para estos efectos, como bien señala Di Rosa, se reconoce que el inversionista tiene la capacidad procesal de demandar directamente en sede arbitral al Estado receptor de la inversión, sin tener que recurrir más al procedimiento tradicional de la protección diplomática. ${ }^{5}$

Además, la instancia arbitral del CIADI es única en su género, ya que todo el procedimiento arbitral hasta la etapa del reconocimiento del laudo arbitral se encuentra libre de la interferencia de las leyes e instancias judiciales de cualquier Estado.

En otras palabras, cuando el arbitraje se desarrolla bajo los auspicios del CIADI, solo serán de aplicación las normas arbitrales del CIADI, con prescindencia absoluta de la legislación arbitral y del Poder Judicial del lugar en el que físicamente se lleve a cabo el procedimiento, como de cualquier otro Estado. ${ }^{6}$

En ese sentido, una de las características particulares del Convenio CIADI es que establece los recursos que cabe interponer contra los laudos arbitrales y dispone que estos serán conocidos y resueltos únicamente hacia el interior del propio CIADI.?

En el presente trabajo, nos concentraremos en analizar esta materia. ${ }^{8}$

which parties can arbitrate their disputes free from the intervention of municipal courts. The ICSID system provides the parties with a great degree of autonomy and flexibility in the resolution of their disputes".

5 DI ROSA, Paolo, The Recent Wave of Arbitrations against Argentina under Bilaterallinvestment Treaties: Background and Principal Legallssues. En: Inter-American Law Review, Vol. 36, No. 1, 2004, p. 42."The right (...) [conferred] on individual investors to seek legal recourse directly against States is a novel feature, as it obviates the need for investors to follow the traditional procedure in international law of obtaining redress against a foreign State by seeking diplomatic protection and espousal of its claim by its state of nationality against the State hosting the investment. An ICSID Tribunal stressed in a recent case:[T] he greatest innovation of ICSID and other systems directed at the protection of foreign investments is precisely that the rights of the investors are not any longer subject to the political and other considerations by their governments, as was the case under the old system of diplomatic protection, often resulting in an interference with those rights. Investors may today claim independently from the view of their governments". El autor se refiere a la decision sobre jurisdicción de 2 de agosto de 2004, en los seguidos por Enron Corporation and Ponderosa Assets, L.P. vs. República de Argentina (Caso ARB/01/3), que se ubica en: http://ita.law.uvic.ca/documents/Enron-DecisiononJurisdiction-FINAL-English.pdf.

6 VAN DEN BERG, Albert Jan, Some Recent Problems in the Practice of Enforcement under the New York and ICSID Conventions. En: ICSID Review. Foreign Investment Law Journal, Vol. 2, No. 2, 1987, p. 441. "The ICSID Convention (...) provides for a comprehensive, self-sufficient system of truly international arbitration in the area of investment disputes. Arbitration under this Convention is administered by the International Centre for the Settlement of Investment Disputes (ICSID), solely on the basis of the provisions of the Convention and the Rules and Regulations issued thereunder, excluding the application of any national arbitration law. In an ICSID arbitration, the place of arbitration is, therefore, legally irrelevant since it does not trigger the application of the national law on arbitration of that place". FELDMAN, Mark B., The Annulment Proceedings and the Finality of ICSID Arbitral Awards. En: ICSID Review. Foreign Investment Law Journal, Vol. 2, No. 1, 1987, pp. 86-87. "[T]he ICSID process is not subject to supervision by national courts. Even if it is necessary to call upon judicial authority for enforcement of an award, the court is not competent to review the award on any grounds whatsoever". GONZALEZ DE COSSIOO, Francisco, The International Centre for Settlement of investment disputes -The Mexican Experience. En: Journal of International Arbitration, Vol. 19, No. 3, 2002, p. 232. "[A]ll aspects of the arbitral procedure are thoroughly covered in the ICSID Convention: the ICSID Convention constitutes the lex arbitri".

7 GAILLARD, Emmanuel, Some Notes on the Drafting of ICSID Arbitration Clauses. En: ICSID Review. Foreign Investment Law Journal, Vol. 3, No. 2, 1988, p. 141. "[T]he arbitral forum has absolutely no legal consequence in ICSID arbitration. This is because the Washington Convention, which created ICSID, is sufficient, as a Convention, to justify the binding character of the whole arbitration system and provide, inter alia, for recourse available against an ICSID arbitration award (...)".

8 Para quien desee profundizar en el análisis del CIADI, leer a: CANTUARIAS SALAVERRY, Fernando, Arbitraje Comercial y de las Inversiones, Lima, 2007, pp. 555-809. 


\section{RECURSOS CONTRA EL LAUDO ARBITRAL CIADI $^{9}$}

El artículo 53(1) del Convenio CIADI dispone expresamente que el "laudo será obligatorio para las partes y no podrá ser objeto de apelación ni de cualquier otro recurso, excepto en los casos previstos en este Convenio".

Esto significa, como explica Parra ${ }^{10}$, que no cabe que las partes planteen recursos distintos a los dispuestos expresamente en el Convenio CIADI, como tampoco procede que las partes pacten la renuncia al ejercicio de los remedios que otorga esta Convención.
Pasemos a analizar cada uno de los recursos que cabe interponer conforme al Convenio CIADI.

\section{RECURSO DE SUPLEMENTACIÓN Y DE RECTIFICACIÓN}

El primer recurso que cabe contra el laudo arbitral y que debe presentarse dentro de los 45 días contados desde la fecha en que fue notificado el fallo, es el de suplementación en caso se haya omitido resolver algún punto controvertido o de rectificación cuando deba corregirse algún error material, aritmético o similar (artículo 49(2) del Convenio (IADI). ${ }^{11}$

9 De conformidad con lo dispuesto en el artículo 48(2) de las Reglas Procesales Aplicables a los Procedimientos de Arbitraje (en adelante simplemente "Reglas de Arbitraje"), el laudo arbitral se considera dictado en la fecha en que sean despachadas a las partes las copias certificadas correspondientes. A partir de ese momento, corren los plazos para plantear los recursos que vamos a analizar seguidamente. Las Reglas de Arbitraje se ubican en: http://icsid. worldbank.org/ICSID/StaticFiles/baiscdoc-spa/CRR Spanish-final.pdf.

10 PARRA, Antonio R., The Limits of Party Autonomy in Arbitration Proceedings under the ICSID Convention. En: The ICC International Court of Arbitration Bulletin, Vol. 10, No. 1, 1999, p. 32. "Article 53(1) of the Convention (...) provides in categorical terms that an award made pursuant to the Convention shall be binding on the parties and not subject to any appeal or to any other remedy except those provided for in the Convention. The parties, therefore, cannot validly agree that the award may be appealed or otherwise proceeded against outside the confines of the Convention. Nor, on the other hand, can the parties bind themselves not to seek the remedies provided for in the Convention. The provisions of the Convention on those remedies do not offer that option".

11 Artículo 49(2) del Convenio CIADI. "A requerimiento de una de las partes, instado dentro de los 45 dias después de la fecha del laudo, el Tribunal podrá, previa notificación a la otra parte, decidir cualquier punto que haya omitido resolver en dicho laudo y rectificar los errores materiales, aritméticos o similares del mismo. La decisión constituirá parte dellaudo y se notificará en igual forma que este. Los plazos establecidos en el apartado (2) del Artículo 51 y apartado (2) del Artículo 52 se computarán des de la fecha en que se dicte la decisión". Por su parte, la regla 49 de las Reglas de Arbitraje establece: "(1) Dentro de los 45 días después de la fecha en que se haya dictado un laudo, cualquiera de las partes podrá solicitar. de conformidad con lo dispuesto en el Artículo 49(2) del Convenio, una decisión que suplemente o que rectifique el laudo. Dicha solicitud deberá ser presentada por escrito al secretario general. La solicitud deberá:

(a) identificar el laudo de que se trata;

(b) señalar la fecha de la solicitud;

(c) detallar:

(i) toda cuestión que el Tribunal, a juicio de la parte solicitante, hubiere omitido decidir en el laudo, y

(ii) todo error en el laudo que la parte solicitante pida que se rectifique; $e$

(d) ir acompañada del derecho de registro de la solicitud.

(2) Al recibir la solicitud y el derecho de registro, el secretario general, sin dilación:

(a) registrará la solicitud;

(b) notificará a las partes el acto de registro:

(c) enviará a la otra parte una copia de la solicitud y de todos los documentos que se hayan acompañado; y

(d) enviará a cada uno de los miembros del Tribunal una copia de la notificación del acto de registro, junto con una copia de la solicitud y de todos los documentos que la acompañan.

(3) El Presidente del Tribunal consultará a los demás miembros acerca de la necesidad de que el Tribunal se reúna para considerar la solicitud. El Tribunal fijará un plazo para que las partes presenten sus observaciones sobre la solicitud y determinará qué procedimiento deberá seguirse para considerar lo pedido.

(4) Las Reglas 46-48 se aplicarán mutandis mutandis a toda decisión del Tribunal tomada de conformidad con esta Regla.

(5) Si el secretario general recibiere una solicitud después de 45 dias contados desde la fecha en que se haya dictado un 
Hasta donde tenemos conocimiento, se ha propuesto este recurso respecto de laudos arbitrales en seis casos, a saber: Amco Asia Corporation, Pan American Development Ltd. y P.T. Amco Indonesia vs. República de Indonesia (Caso ARB/81/1), Liberian Eastern Timber Corporation y Letco Lumber Industry Corporation vs. República de Liberia (Caso ARB/83/2), Compañía del Desarrollo de Santa Elena S.A. vs. República de Costa Rica (Caso ARB/96/1) $)^{12}$, Emilio Agustín Maffezini vs. Reino de España (Caso ARB/97/7) ${ }^{13}$, Alex Genin y otros vs. República de Estonia (Caso ARB/99/2) ${ }^{14}$ y Noble Ventures, Inc. vs. Rumania (Caso ARB/01/11)..$^{15}$

Además, en el caso Empresas Lucchetti S.A. y Lucchetti Perú S.A. vs. República del Perú (Caso $\mathrm{ARB} / 03 / 4$ ), el Estado peruano solicitó la rectificación de la Decisión de Anulación del Comité Ad Hoc que conoció de dicho recurso, el cual fue aceptado al tratarse de un error formal. ${ }^{16}$
Por último, en Compañía de Aguas del Aconquija S.A. y Vivendi Universal vs. República Argentina (Caso ARB/97/3), el Estado argentino también solicitó la suplementación y la rectificación de la Decisión de Anulación del Comité Ad Hoc que resolvió dicho recurso, destacando de esta decisión la siguiente afirmación: "(...) es importante declarar que ese procedimiento y cualquier decisión de suplementación o rectificación que pueda resultar, de ninguna manera consiste en un medio de apelación o de otra manera para revisar el fondo de la decisión por medio de la suplementación o rectificación"."

\section{RECURSO DE ACLARACIÓN}

Cabe solicitar la aclaración del laudo arbitral en caso existan dudas acerca de su sentido o alcance (artículo 50(1) del Convenio CIADI). ${ }^{18}$

laudo, rechazará el registro de la solicitud e informará de inmediato de lo anterior a la parte que haya presentado tal solicitud".

United Nations Conference on Trade and Development, Course on Dispute Settlement - International Centre for Settlement of Investment Disputes, 2.8. Post-Award Remedies and Procedures, United Nations, Nueva York y Ginebra, 2003, p. 7. "This remedy is designed for inadvertent omissions and minor technical errors. It is not designed for a substantive review of the decision. Rather, it enables the tribunal to correct mistakes that may have occurred in the award's drafting in a simple way".

12 La decisión de 8 de junio de 2000 se ubica en: http://icsid.worldbank.org/ICSID/FrontServlet?requestType=CasesR H\&actionVal=showDoc\&docld=DC540_En_\&caseld=C152.

13 La decisión de 31 de enero de 2001, se encuentra en: http://icsid.worldbank.org/ICSID/FrontServlet?requestType= CasesRH\&actionVal=showDoc\&docld=DC567_Sp\&caseld=C163.

14 La decisión de 4 de abril de 2002 se ubica en: http://icsid.worldbank.org/ICSID/FrontServlet?requestType=CasesRH \&actionVal=showDoc\&docld=DC593_En_\&caseld=C178.

15 La decisión de 19 de mayo de 2006 no ha sido publicada. Leer a: PARRA, Antonio R., The Limits of Party Autonomy in Arbitration Proceedings under the ICSID Convention, Ob. Cit., p. 30; y MARZORATTI, Osvaldo J., Algunas reflexiones sobre el alcance de la protección de las inversiones en el marco de los tratados firmados por Argentina. En: Revista Peruana de Arbitraje, No. 1, Lima, 2005, pp. 110-111.

16 La decisión de 30 de noviembre de 2007 se ubica en: http://icsid.worldbank.org/ICSID/FrontServlet?requestType= CasesRH\&actionVal=showDoc\&docld=DC688_Sp\&caseld=C163.

17 La decisión de 28 de mayo de 2003, se ubica en: http://icsid.worldbank.org/ICSID/FrontServlet?requestType=Cases RH\&actionVal=showDoc\&docld=DC554_Sp\&caseld $=C 225$.

18 Artículo 50 del Convenio CIADI.- "(1) Si surgiere una diferencia entre las partes acerca del sentido o alcance del laudo, cualquiera de ellas podrá solicitar su aclaración mediante escrito dirigido al secretario general. (2) De ser posible, la solicitud deberá someterse al mismo Tribunal que dictó el laudo. Si no lo fuere, se constituirá un nuevo Tribunal de conformidad con lo dispuesto en la Sección 2 de este Capítulo. Si el Tribunal considera que las circunstancias lo exigen, podrá suspender la ejecución del laudo hasta que decida sobre la aclaración". 
Este es un recurso que puede presentarse en cualquier momento, condicionado a que exista una verdadera disputa entre las partes. ${ }^{19}$

Como este recurso no tiene plazo, en caso el tribunal arbitral original no pueda conocer de la solicitud, se constituirá un nuevo órgano arbitral para estos efectos. ${ }^{20}$

Por la misma razón de inexistencia de plazo, su interposición o pendencia no evitará la ejecución del laudo arbitral. Sin embargo, como la decisión a la que se arribe forma parte del laudo arbitral ${ }^{21}$, el tribunal que conozca de este recurso puede, si lo considera pertinente, suspender la ejecución del laudo arbitral hasta que resuelva el pedido. ${ }^{22}$

Hasta donde tenemos conocimiento, existe un solo caso en el que se ha solicitado una aclaración del laudo arbitral: Wena Hotels Limited vs. República Árabe de Egipto (Caso ARB/98/4).
En efecto, en junio de 2004 Wena solicitó la interpretación del laudo arbitral de fecha 8 de diciembre de 2000, que había condenado a Egipto a pagarle una indemnización debido a una expropiación. Su solicitud se debió a que si bien el tribunal arbitral declaró que había existido una "expropiación" en 1991 que había impedido a Wena gozar de su "derecho fundamental de propiedad" respecto de sus intereses en los arrendamientos de dos hoteles de lujo, Egipto y sus entidades públicas habian iniciado procesos judiciales para el cobro de los arrendamientos de uno de los hoteles. Wena solicitó que se aclarara si esa expropiación se generó el 1 de abril de 1991 y si precluían las demandas judiciales.

El 31 de octubre de 2005, un tribunal arbitral del que formó parte solo uno de los originales árbitros que expidieron el laudo arbitral, consideró en primer lugar que para la procedencia de este recurso se requiere: 1 ) tiene que existir

19 United Nations Conference on Trade and Development, Course on Dispute Settlement - International Centre for Settlement of Investment Disputes, Ob. Cit., 2.8, p. 9. "There must be a specific dispute concerning the meaning or scope of the award". SCHREUER, Christoph, The ICSID Convention: A Commentary, Ob. Cit., pp. 857-858. "The institution of the procedure for interpretation requires the existence of a dispute. Such a dispute must be sufficiently concrete to be susceptible of a specific request for interpretation (...) General complaints about the award's lack of clarity would not be admissible. The existence of a dispute also presupposes a certain degree of communication between the parties demonstrating a difference of opinion. Moreover, the dispute must have some practical relevance to the award's implementation. Abstract discussions concerning the award's theoretical implications would not amount to a dispute as to the meaning or scope of an award (...)".

20 La Regla 51 de las Reglas de Arbitraje, dispone sobre este particular: "(1) Al registrar una solicitud de aclaración o revisión de un laudo, el secretario general deberá, inmediatamente:

(a) enviar a cada miembro del Tribunal original una copia de la notificación del acto de registro, junto con una copia de la solicitud y de cualquier documento que la acompañe; y

(b) requerir a cada miembro del Tribunal que le informe dentro de un plazo determinado si está dispuesto a particular en la consideración de la solicitud.

(2) Si todos los miembros del Tribunal manifiestan su voluntad de participar en la consideración de la solicitud, el secretario general asi lo notificará a los miembros del Tribunal y a las partes. En cuanto se envíen estas notificaciones, se considerará que se ha reconstituido el Tribunal.

(3) Si el Tribunal no pudiese reconstituirse de acuerdo con lo dispuesto en el párrafo (2), el secretario general lo notificará a las partes y las instará a proceder, en cuanto sea posible, a constituir un nuevo Tribunal, incluyendo la misma cantidad de árbitros, siguiendo el mismo método, como el Tribunal original". Sobre este particular, leer a: SCHREUER, Christoph, The ICSID Convention: A Commentary, Ob. Cit., pp. 864-965.

21 Artículo 53(2) del Convenio CIADI.-" (2) A los fines previstos en esta Sección, el término "laudo" incluirá cualquier decisión que aclare, revise o anule el laudo, según los Artículos 50, 51 0 52".

22 A diferencia de lo que sucede con los recursos de revisión y de anulación, cuya sola interposición suspende los efectos del laudo arbitral hasta que el tribunal arbitral correspondiente se pronuncie acerca de si continua o levanta la suspensión, aquí hay que solicitar expresamente la suspensión y lograr la decisión por parte del colegiado a cargo del caso. 
una disputa entre las partes acerca del sentido o alcance del laudo arbitral; y 2) el propósito de la solicitud efectivamente debe ser el de pedir una inter.pretación del laudo arbitral. ${ }^{23}$

Sobre el primer requisito, el tribunal afirmó que la disputa debe ser lo suficientemente concreta para ser susceptible de una interpretación y, además, ambas partes tienen que demostrar que tienen posiciones divergentes respecto al sentido $o$ alcance del laudo arbitral que se pide aclarar. $^{24}$

Respecto al segundo requisito, el colegiado consideró, al amparo de precedentes internacionales, que la disputa tiene que estar referida al sentido o alcance de la parte resolutiva del laudo arbitral. ${ }^{25}$
Determinado el marco conceptual, el tribunal arbitral consideró que efectivamente en este caso había una disputa entre las partes acerca de los alcances de la parte resolutiva del laudo arbitral, por lo que procedió a aclarar el significado del término "expropiación", la fecha en que ocurrió y la invalidez de las acciones de cobro de una supuesta merced conductiva que Egipto pretendía ejecutar. ${ }^{26}$

\section{RECURSO DE REVISIÓN}

Otro recurso que puede deducirse es la revisión del laudo arbitral, "fundada en el descubrimiento de algún hecho que hubiera podido influir decisivamente en el laudo, y siempre que, al tiempo de dictarse el laudo, hubiere sido desconocido por el Tribunal y por la parte que inste

23 Parágrafo 76: "First, there has to be a dispute between the original parties as to the meaning or scope of the award; second, the purpose of the application must be to obtain an interpretation of the award".

24 Parágrafo 81: "The existence of a dispute as to the meaning or scope of an award requires that the dispute is sufficiently concrete to be susceptible of a specific request for interpretation (...) the two parties have actually exposed their divergence of views on definite points in relation to the award's meaning or scope". Además, el tribunal arbitral (parágrafo 87) estuvo de acuerdo con Schreuer, quien considera que es necesario que la disputa tenga una importancia práctica y no simplemente teórica: "IT]he dispute must at least have some practical relevance to the award's implementation; mere theoretical discussions about the award's meaning or scope are not sufficient".

25 Parágrafo 82: "[T] he dispute must relate to the meaning or scope of what has been decided with binding force, thus in principle to the award's operative section, a condition well adhered to by international practice and confirmed by opinions of scholars (...)". Para estos efectos, el Tribunal Arbitral citó el caso Chrozów Factory (Interpretación de las sentencias 7 y 8 , fallo de 16 de diciembre de 1927) como el caso Túnez vs. Libia (aplicación para la revisión e interpretación del fallo de 24 de febrero de 1982, en el "Case Concerning the Continental Shelf", fallo de 10 de diciembre de 1985): "The question is therefore limited to whether the difference of views between the Parties which has manifested itself before de Court is 'a difference of opinion between the Parties as to those points in the judgment in question which have been decided with binding force'. Including 'A difference of opinion as to whether a particular point has or has not been decided with binding force"'. Fouchard, Gaillard, Goldman on International Commercial Arbitration, GAILLARD, Emmanuel y SAVAGE, John (editores), Kluwer Law international, 1999, p. 776. "The interpretation of an arbitral award is only really helpful where the ruling, which is generally presented in the form of an order, is so ambiguous that the parties could legitimately disagree as to its meaning. By contrast, any obscurity or ambiguity in the grounds for the decision does not warrant a request for interpretation of the award".

Sin embargo, cabe aclarar que en el citado caso Túnez vs. Libia, la Corte aclaró que, si bien la aplicación de la interpretación se debe dirigir a clarificar alguna ambigüedad de la parte resolutiva del fallo, uno puede recurrir a la parte considerativa para estos efectos, de ser necesario. Sobre este particular, leer a: CANTUARIAS SALAVERRY, Fernando, Arbitraje Comercialy de las Inversiones, Ob. Cit., pp. 359-368.

26 "(i) such term, used in the Award in connection with the awarding of damages and interest to Wena, must be understood to mean that the expropriation constituted a total and permanent deprivation of Wena's fundamental rights of ownership, i.e. its rights to make use of its investment made under the Luxor Lease and to enjoy the benefits of such investments in accordance with such Lease; (ii) such expropriation occurred as of 1991; (iii) subsequent legal actions by Egypt, as a party to the arbitration, that presume the contrary are precluded". Sin embargo, el tribunal arbitral consideró que no le correspondia interpretar un último pedido de Wena acerca de que no debían existir reclamos adicionales como consecuencia de la expropiación, ya que este pedido escapaba al recurso, debido a que no había sido materia de pronunciamiento en el laudo arbitral. La decisión se ubica en: http://ita.law.uvic.ca/documents/WenalnterpretationDecision.pdf. 
la revisión y que el descubrimiento de esta no se deba a su propia negligencia" (artículo 51 del Convenio $(\mid A D I) .27$

Esta petición deberá presentarse dentro de los noventa días siguientes de descubierto el hecho y no después de los tres años de dictado el laudo arbitral. De ser posible, la solicitud deberá someterse al tribunal arbitral original. De lo contrario, se constituirá un nuevo órgano arbitral para estos efectos. ${ }^{28}$

La nueva prueba debe estar referida necesariamente a hechos y no al derecho, y debe tratarse de hechos desconocidos para el tribunal arbitral y para la parte que los introduce, que puedan afectar decididamente el contenido del laudo arbitral. En otras palabras, deben tratarse de hechos que, de haber sido conocidos en su momento, hubieran podido llevar a un fallo distinto del tribunal arbitral. ${ }^{29}$

Al tratarse de una solicitud que implica la afirmación de que existen hechos relevantes recién descubiertos que alterarían significativamente el contenido del laudo arbitral, si la parte interesada pide junto con su recurso la

28 Ver Regla 51 de las Reglas de Arbitraje (Supra, cita No. 20). vention, Ob. Cit., pp. 29-30. suspensión de la ejecución del laudo arbitral, esta será concedida automáticamente hasta que el tribunal arbitral decida al respecto. Por su parte, los árbitros, en caso las circunstancias lo exijan, se encuentran autorizados a disponer la suspensión de la ejecución del laudo arbitral hasta que decidan sobre la revisión. ${ }^{30}$

A la fecha, nosotros hemos identificado que solo en el caso American Manufacturing \& Trading Inc. vs. República de Zaire (Caso ARB/93/1) se solicitó la revisión del laudo arbitral dictado el 21 de febrero de 1997, pero las partes transigieron su controversia en el camino. ${ }^{31}$

\section{RECURSO DE ANULACIÓN}

\section{Cuestiones generales}

El artículo 52 del Convenio CIADI establece que dentro de los ciento veinte días de dictado el laudo arbitral ${ }^{32}$, cualquiera de las partes podrá solicitar su anulación, conforme a cinco causales taxativas..$^{33}$

Se trata de un recurso que no permite revisar el fondo de la controversia ni modificar la

27 Revisar además las reglas 50 y 51 de las Reglas de Arbitraje. United Nations Conference on Trade and Development, Course on Dispute Settlement - International Centre for Settlement of Investment Disputes, Ob. Cit., 2.8, p. 11. "Revision involves a substantive alteration of the original award on the basis of newly discovered facts that were unknown when the award was rendered (...) Revision is contingent upon the discovery of new facts. These must be capable of affecting the award decisively. The new element must be one of fact and not of law".

29 SCHREUER, Christoph, The ICSID Convention: A Commentary, Ob. Cit., p. 874. "The fact must be able to affect the award decisively. It must be of such a nature that it could have led to a different decision had it been known to the tribuna (...) The fact must be new in the sense that it was unknown to the tribunal and to the party making the application".

30 Sobre el tema, leer a: PARRA, Antonio R., The Limits of Party Autonomy in Arbitration Proceedings under the ICSID Con-

31 REED, Lucy; PAULSSON, Jan y BLACKABY, Nigel, Guide to ICSID Arbitration, Kluwer Law International, La Haya, 2004, p. 98. "As of January 2003, there had been only one request for revision. In that instance, the parties settled the relevant case before the application could be heard".

32 Conforme al artículo 52(2) del Convenio CIADI, si la causal invocada es la de corrupción de algún miembro del tribunal arbitral, los ciento veinte días comenzarán a computarse desde el descubrimiento del hecho. Sin embargo, la solicitud deberá presentarse dentro de los tres años siguientes de dictado el laudo arbitral. Por su parte, si se ha solicitado la aclaración o la rectificación del laudo arbitral, el plazo de ciento veinte días comenzará a correr desde la fecha en que sea notificada la decisión.

33 Artículo 52(1) del Convenio CIADI.-"(1) Cualquiera de las partes podrá solicitar la anulación del laudo mediante escrito dirigido al secretario general fundado en una o más de las siguientes causas: 
decisión contenida en el laudo arbitral ${ }^{34}$, ya que únicamente puede atacar aspectos formales que le restan legitimidad al fallo y que pueden desembocar en su invalidación total o parcial ${ }^{35}$. Estamos pues ante la presencia de un recurso excepcional, limitado a causales taxativas, que no permite revisar el fondo de la controversia, sea en los hechos o en el derecho. ${ }^{36}$

Este recurso excepcional se fundamenta en el hecho de que, como correctamente opina Reis-

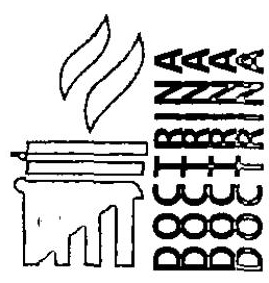

que el Tribunal se hubiere constituido incorrectamente;

(b) que el Tribunal se hubiere extralimitado manifiestamente en sus facultades;

(c) que hubiere habido corrupción de algún miembro del Tribunal;

(d) que hubiere quebrantamiento grave de una norma de procedimiento; 0

(e) que no se hubieren expresado en el laudo los motivos en que se funde".

SCHREUER, Christoph, The ICSID Convention: A Commentary, Ob. Cit., p. 1030. "Annulment is restricted to the five grounds listed in Art. 52(1). The ad hoc committee may not annul on other grounds. A request for annulment must specify which of these grounds is (or are) invoked. Parties to annulment proceedings have invariably presented their grievances in terms of these grounds (....)".

34 Fallo sobre anulación del Comité Ad Hoc en los seguidos por CDC Group ple vs. República de Seychelles (Caso ARB/02/14) de 29 de junio de 2005:"34. Article 52(1) looks not to the merits of the underlying dispute as such, but rather is concerned with the fundamental integrity of the tribunal, whether basic procedural guarantees were largely observed, whether the Tribunal exceeded the bounds of the parties' consent, and whether the Tribunal's reasoning is both coherent and displayed". La decisión se ubica en: http://ita.law.uvic.ca/documents/CDSeychellesAnnulment_Decision.pdf. Decisión sobre anulación del Comité Ad Hoc en los seguidos por Patrick Mitchell vs. República Democrática del Congo (Caso ARB/99/7) de 1 de noviembre de 2006:"[A]n annulment proceeding is different from an appeal procedure and that it does not entail the carrying out of a substantive review of an award (...)". El fallo se ubica en: www.investmentclaims.com/IIC_172_(2006).pdf.

35 United Nations Conference on Trade and Development, Course on Dispute Settlement - International Centre for Settlement of Investment Disputes, Ob. Cit., 2.8, p. 13. "Annulment is different from an appeal. Appeal may result in the modification of the decision. Annulment results in the legal destruction of the original decision without replacing it. An ad hoc committee acting under the ICSID Convention may not amend or replace the award by its own decision on the merits (...) Annulment is only concerned with the basic legitimacy of the process of decision but not with its substantive correctness. Therefore, annulment is based on a very limited number of fundamental standards". SCHREUER, Christoph, The ICSID Convention: A Commentary, Ob. Cit., pp. 891-892, identifica que la diferencia entre ambos recursos está referido al resultado del proceso y a los temas que revisar en cada uno de ellos: "As to the first, the result of a successful application for an annulment is the invalidation of the original decision. The result of a successful appeal is its modification. A decision-maker exercising the power to annul has only the choice between leaving the original decision intact or declaring it void. An appeals body may substitute its own decision on the merits for the decision that it has found to be deficient (...)

As to the second element, annulment is only concerned with the legitimacy of the process of decision: it is not concerned with its substantive correctness. Appeal is concerned with both".

36 SMIT, Hans, Contractual modification of the scope of Judicial Review of Arbitral Awards. En: The American Review of International Arbitration, Vol. 8, No. 2, 1997, pp. 148-149. "II]t is universally accepted rule that arbitral awards may not be reviewed on alleged errors of fact or law (...)

Exclusion of judicial review of arbitral awards for errors of fact or law is one of the foundations on which the social desirability and acceptance of arbitration is firmly built. For if arbitral awards could be reviewed for errors of law or fact, arbitration would easily degenerate into a device for adding still another instance to the usual three instances of litigation in the ordinary courts. It is exactly to avoid this socially most reprehensible consequence that the law straightforwardly excludes review of arbitral awards for errors of fact or law". Decisión de anulación de 21 de marzo de 2007, en los seguidos por MTD Equity Sdn Bhd. \& MTD Chile S.A. vs. República de Chile (Caso ARB/01/7): "54. No doubt annulment committees have a role to perform within the ICSID system in ensuring the fundamental justice of the arbitral process' (...) the role of an ad hoc committee in the ICSID system is a limited one. It cannot substitute its determination on the merits of that of the tribunal. Nor can it direct a tribunal on a resubmission how it should resolve substantive issues in dispute. All it can do is annul the decision of the tribunal: it can extinguish a res judicata but on a question of merits it cannot create a new one". La decision se ubica en: http://investmentclaims.com/IIC_177_(2007).pdf. Fallo del Comité Ad Hoc, de 22 de diciembre de 1989, en los seguidos por Maritime International Nominees Establishment vs. República de Guinea (Caso ARB/84/4): "Article 51(1) makes it clear that annulment is a limited remedy. This is further confirmed by the exclusion of review of the merits of awards by Article 53. Annulment is not a remedy against an incorrect decision. Accordingly, an ad hoc Committee may not in fact reverse an award on the merits under the guise of applying Article 52". 
$\operatorname{man}^{37}$, el arbitraje es una delegación restrictiva de poderes para resolver ciertas controversias que requiere de algún mecanismo de control, porque de lo contrario el arbitraje dejaría de ser tal y se convertiría potencialmente en un abuso. Este autor señala que el arbitraje es ventajoso para las partes porque les permite acceder a una instancia distinta al Poder Judicial para resolver sus conflictos; pero el arbitraje también es beneficioso para la sociedad porque permite que se resuelvan controversias sin mayor costo social. Siendo pues que el arbitraje no solo interesa a las partes sino también a la sociedad, deben articularse mecanismos que eviten el abuso o controlen el exceso de poder de los árbitros; lo que Reisman denomina exces de pouvoir. ${ }^{38}$

Como explica Garro ${ }^{39}$, el control del exceso de poder de los árbitros debe limitarse a cues- tiones fundamentales, porque de lo contrario "las partes se encontrarian envueltas en penosos y dilatados trámites (...) que el acuerdo arbitral apunta precisamente a eliminar".

Obviamente el eliminar la posibilidad de apelación afecta el principio de corrección en los fallos ${ }^{40}$, pero abona, qué duda cabe, en favor de otro principio tan o más importante, cual es el de la eficacia de las decisiones. En todo caso, el recurso de anulación se constituye en un mecanismo que, en el fondo, resulta ser un balance adecuado entre ambos principios. ${ }^{41}$

Por último, cabe destacar que las causales de anulación dispuestas por el Convenio CIADI se asemejan a las existentes en el ámbito privado. ${ }^{42}$

37 W. Michael Reisman, Systems of Control in International Adjudication \& Arbitration - Breakdown and Repair, Duke University Press, 1992, p. 1."Arbitration is a delegated and restricted power to make certain types of decisions in certain prescribed ways. Any restricted delegation of power must have some system of control". REDFERN, Alan y HUNTER, Martin, Law and Practice of International Commercial Arbitration, Sweet \& Maxwell, Londres, 1986, pp. 197-198. "Although the modern trend is to allow decisions of arbitral tribunals to go unchallenged, so that they are effectively final and binding upon the parties, the need for some control over the way in which these decisions are reached is recognised by most, if not quite all, systems of law. In particular, it is considered important to ensure that an arbitral tribunal gives the parties a fair hearing and that it only decides matters within its competence, or jurisdiction".

38 REISMAN, W. Michael, Systems of Control in International Adjudication \& Arbitration - Breakdown and Repair, Ob. Cit., p. 6. "Without it, whatever an arbitrator did, no matter how inconsistent it might have been with his instructions, would have produced a binding award. The arbitrator would become an absolute decision-maker and arbitration would lose its character of restrictive delegation. Excés de pouvoir is the conceptual foundation of control for arbitration".

39 GARRO, Alejandro M., El arbitraje en la ley modelo propuesta por la Comisión de las Naciones Unidas para el Derecho Mercantil Internacional y en la nueva legislación española de arbitraje privado: un modelo para la reforma del arbitraje comercial en América Central. En: Arbitraje Comercial y Laboral en América Central, GARRO, Alejandro M. (editor), Transnational Juris Publications, Nueva York, 1990, pp. 51-52.

40 DONOVAN, Donald Francis, Powers of the Arbitrators to /ssue Procedural Orders, Including interim Measures of Protection, and the Obligation of Parties to Abide by such Orders. En: The ICC International Court of Arbitration Bulletin, Vol. 10, No. 1, 1999, p. 71." Justice Robert H. Jackson of the Supreme Court of the United States once observed of that Court that "W] are not final because we are infallible, but we are infallible only because we are final".

41 SCHREUER, Christoph, The ICSID Convention: A Commentary, Ob. Cit., pp. 893-894. "There are two potentially conflicting principles at work in the review process. One is the principle of finality; the other is the principle of correctness. Finality is designed to serve the purpose of efficiency in terms of an expeditious and economical settlement of disputes. Correctness may be an elusive goal that takes time and effort and may involve several layers of control, a phenomenon that is well known for domestic court procedure. In international arbitration the principle of finality is often seen to take precedence over the principle of correctness. The desire to see a dispute settled is regarded as more important than the substantive correctness of the decision. Annulment is the preferred solution to balance these two objectives".

42 POSIN, Daniel Q., Recent Developments in ICSID Annulment Procedures. En: World Arbitration \& Mediation Report, Vol. 13, Vo. 6, 2002, p. 170. "The grounds for seeking an annulment are as broad or broader than any regime for judicially attacking the procedure of an arbitral award". Sobre este particular, leer: CANTUARIAS SALAVERRY, Fernando, Arbitraje Comercialy de las Inversiones, Ob. Cit., pp. 474-535. 


\section{Autoridad que conoce del recurso y sus efectos}

Fuera de la jurisdicción del CIADI, contra un laudo arbitral cabe recurrir en anulación ante el Poder Judicial del lugar del arbitraje. ${ }^{43}$ En cambio, el CIADI establece un procedimiento único en su género que consiste en que el recurso de anulación se presenta exclusivamente ante la propia institución ${ }^{44}$, la que inmediatamente designa un comité ad hoc integrado por tres personas seleccionadas de su Panel de Árbitros, que se encargará de resolver la solicitud..$^{45}$

43 GONZALEZ, Daniel E.; HRITZ, George F.; RIOS, Marcos y LORENZO, Richard C., International Arbitration: Practical Considerations with a Latin American Focus. En: The Journal of Structured and Project Finance, Vol. 9, No. 1, 2003, p. 38. "The parties' choice of the place, 'seat', or 'forum' where the arbitration shall take place and where the award must be issued (...) is a crucial element of every arbitration clause. The law of the forum either determines or materially affects a number of all-important issues, such as how the award will be enforced, the procedural rules that may apply to the arbitration, under what circumstances and to what extent the award may be reviewed and vacated (...) the degree of local courts' intervention in the arbitration, and the availability of discovery and other evidentiary matters". Sobre este particular, leer: CANTUARIAS SALAVERRY, Fernando, Arbitraje Comercialy de las Inversiones, Ob. Cit., pp. 65-78 y 373-396.

44 Ver reglas 50 y 52 de las Reglas de Arbitraje. SCHREUER, Christoph, The ICSID Convention: A Commentary, Ob. Cit., p. 1084. "This independence from national procedures for review arbitral awards means that the place of arbitration in ICSID proceedings is irrelevant for the award's validity and enforcement. ICSID arbitration is delocalized and independent of judicial control in the country where the proceedings take place and the award is rendered (...) Consequently, a party to ICSID proceedings may not initiate action before a domestic court to seek the annulment or another form of review of an ICSID award. A court of a State that is a party to the ICSID Convention would be under an obligation to dismiss such an action". SACERDOTI, Giorgio, Investment Arbitration under ICSID and UNCITRAL Rules: Prerequisites, Applicable Law, Review of awards. En: ICSID Review. Foreign Investment Law Journal, Vol. 19, No. 1, 2004, pp. 42-43. El autor cita a HIRSCH, quien afirma: "IT]he Convention prohibits the parties from having recourse to municipal courts in order to obtain additional relief. This prohibition is consistent with the aim of creating an autonomous judicial mechanism, independent of municipal legal systems (in order to ensure the neutrality of the arbitration proceedings at the Centre). [...] The intention of the drafters of the Convention that the arbitration proceedings conducted at the Centre be independent of municipal courts prescribed the provisions of the Convention prohibiting recourse to remedies outside the Centre. However, the proscription of external remedies obliged the Centre to supply, concurrently, alternative legal remedies necessary for the conduct of proper legal proceedings. [This] enables the losing party to challenge the validity of the arbitral awards by means of the Centre's internal control mechanism".

45 Conforme al artículo 52(2) del Convenio CIADI y la regla 54 de las Reglas de Arbitraje, una parte puede solicitar junto con el pedido de anulación del laudo arbitral la suspensión provisional de la ejecución hasta que el comité ad hoc se pronuncie al respecto. Por su parte, la regla 54(2) de las Reglas de Arbitraje establece que una vez instalado el comité ad hoc $y$, a pedido de parte, dentro de los treinta días este panel deberá pronunciarse acerca de si la suspensión de la ejecución del laudo arbitral debe mantenerse hasta que se dicte fallo sobre la anulación.

Sobre este particular, el comité ad hoc en su decisión de 30 de noviembre de 2004 en los seguidos por Patrick Mitchell vs. República Democrática del Congo (Caso ARB/99/7), manifestó que "[n]o indication is given as to what kind of circumstances require a stay; therefore the Committee is free to evaluate the arguments of the parties in view of the particularities of each case". Sin embargo, seguidamente identificó que en todos los casos en los que se había iniciado un proceso de anulación de un laudo arbitral y se había pedido la suspensión de su ejecución, esta se había concedido (Amco Asia Corporation, Pan American Development Ltd. y P.T. Amco Indonesia vs. República de Indonesia (Caso ARB/81/1) en dos oportunidades, Maritime International Nominees Establishment vs. República de Guinea (Caso ARB/84/4), Wena Hotels Limited vs. República Árabe de Egipto (Caso ARB/98/4) y CDC Group plc vs. República de Seychelles (Caso ARB/02/14)). En esta decisión se hizo referencia, además, a que en todos los casos también se analizó el tema de las garantías que debía otorgar aquel que solicitara la suspensión de la ejecución del laudo arbitral, identificándose que en cuatro de ellos (Amco Asia Corporation, Pan American Development Ltd. y P.T. Amco Indonesia vs. República de Indonesia (Caso ARB/81/1) en dos oportunidades, Wena Hotels Limited vs. República Árabe de Egipto (Caso ARB/98/4) y CDC Group plc vs. República de Seychelles (Caso ARB/02/14)) se había ordenado la entrega de una garantía y solo en uno de los casos (Maritime International Nominees Establishment vs. República de Guinea (Caso ARB/84/4)) se dispuso la suspensión sin que se exigiera garantía alguna. Cabe aclarar que también en el caso Patrick Mitchell vs. República Democrática del Congo (Caso ARB/99/7) se ordenó la suspensión sin garantía alguna.

Ver además las decisiones acerca de la suspensión de la ejecución de los laudos arbitrales, en los seguidos por MTD Equity Sdn. Bhd. y MTD Chile S.A. vs. Chile (Caso ARB/01/7), Repsol YPF Ecuador S.A. vs. Empresa Estatal Petróleos

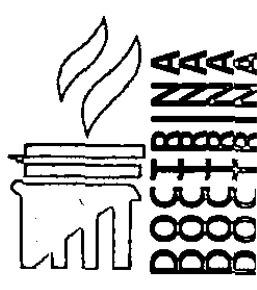


Es más, si se llega a anular el laudo arbitral, la diferencia se someterá nuevamente ante otro tribunal arbitral CIADI si así lo solicita alguna de las partes (artículo 52 del Convenio CIADI). ${ }^{46}$

En efecto, en este caso lo que se someterá a conocimiento de un nuevo tribunal arbitral será la porción del laudo arbitral anulado, ya que si una parte del fallo no es anulado, la decisión será cosa juzgada. Además, conforme lo dispone el artículo 52(6) del Convenio CIADI, solo se someterá a conocimiento del nuevo tribunal arbitral la disputa original anulada. ${ }^{47}$

Asi, por ejemplo, en el caso Compañía de Aguas del Aconquija S.A. y Vivendi Universal S.A. vs. República Argentina (Caso ARB/97/3), las demandantes sometieron a conocimiento del tribunal arbitral supuestas violaciones al BIT FranciaArgentina que habrían sido cometidas por diferentes autoridades federales y provinciales argentinas respecto al Contrato de Concesión

del Ecuador (Petroecuador) (Caso ARB/01/10) y CMS Gas Transmission Company vs. República de Argentina (Caso ARB/01/8), de fecha 1 de junio de 2005, 22 de diciembre de 2005 y 1 de setiembre de 2006, respectivamente. En los tres casos se ordenó mantener la suspensión de la ejecución de los laudos arbitrales, pero solo a Ecuador se le ordenó la entrega de una garantía. Respecto de Argentina y Chile, se hizo saber que no era necesaria una garantía, porque ambos Estados habian asegurado que cumplirian con lo resuelto en el laudo arbitral en caso el procedimiento de anulación les fuera contrario. Estas decisiones se ubican en: http://ita.law.uvic.ca/documents/ MTD-Stay_001.pdf, http://icsid.worldbank.org/ICSID/FrontServlet?requestType=CasesRH\&actionVal=showDoc\&d ocld=DC617_Sp\&caseld=C203 y http://ita.law.uvic.ca/documents/CMS-StayDecision.pdf, respectivamente. Cabe destacar que, ante el incumplimiento en la entrega de la garantía ordenada, el comité ad hoc en el caso Repsol YPF Ecuador S.A. vs. Empresa Estatal Petróleos del Ecuador (Petroecuador) (Caso ARB/01/10) dispuso mediante Resolución No. 4 de 22 de febrero de 2006, dejar sin efecto la suspensión de la ejecución del laudo arbitral (la resolución se ubica en: http://icsid.worldbank.org/ICSID/FrontServlet?requestType=CasesRH\&actionVal=showDoc\&docld=D C618_Sp\&caseld=C203).

Por último, destacamos que en la decisión de 28 de diciembre de 2007 sobre la suspensión de la ejecución del laudo arbitral dictado entre Azurix Corp. vs República Argentina (Caso ARB/01/12), el comité ad hoc fue de la opinión que el ejercicio de la anulación del laudo es un derecho que "no está condicionado expresamente en el Convenio al cumplimiento del requisito de que la parte perdedora deba proporcionar una garantia como 'precio' de una suspensión" y de que "es la demandante la que debe formular sus argumentos favorables a la presentación de una garantia en el contexto de una orden de suspensión". La decisión se ubica en: http://icsid.worldbank.org/ICSID/FrontServlet?reques tType=CasesRH\&actionVal=showDoc\&docld=DC692_Sp\&caseld=C5.

46 REISMAN, W. Michael, Systems of Control in International Adjudication \& Arbitration -Breakdown and Repair-, Ob. Cit., p. 50. "The innovation in ICSID was the control entity to which claims for nullification were to be submitted. Once the request has been lodged, the chairman of the ICSID Administrative Council (ex officio the president of the World Bank) appoints an ad hoc committee of three persons from a panel of names proposed by states' members and kept by the secretary-general, none of whom may have the nationality of the state-party of the foreign investor. Name notwithstanding, the committee is, in effect, another tribunal, following the same procedures prescribed in the convention for the original tribunal, though its mandate is more circumscribed than the tribunal whose award it is reviewing. In the course of its proceedings, the committee may stay enforcement of the award. If it finds that there has been a violation of one or more of the standards, the ad hoc committee is authorized to annul the award in whole or in part. If the award is nullified by the committee, either party may submit the dispute to a new tribunal, constituted in accordance with the convention".

47 SCHREUER, Christoph, The ICSID Convention: A Commentary, Ob. Cit., pp. 1070-1071. "The reference in Art. 52(6) to 'the dispute' which may be submitted to a new tribunal suggest that it is the original dispute that was before the first tribunal which falls to be relitigated. If there was partial annulment, it is the annulled portion of the original dispute that must be decided. This would indicate that the parties may not introduce new claims before the new tribunal.

Before the new Tribunal in Amco II, Indonesia introduced a counter-claim for tax fraud. The issue of tax fraud had been discussed in the original proceeding as one of the arguments justifying the revocation of the investment license. Therefore, before the first Tribunal it was raised by Indonesia merely as a defense and not as a counter-claim.

The new Tribunal came to the conclusion that Art. 46 dealing with counter-claims, did not give a party the right to introduce new counter-claims in a resubmitted case (...) it said:

Article 52 is not a provision for starting a totally new arbitration, restricted only by the requirements of Article 25. Rather, it is a procedure for resubmission of an existing dispute in respect of which Article 25 jurisdiction exists".

Reglas 55(1) y 55(3) de las Reglas de Arbitraje.- "Nueva sumisión de una diferencia después de la anulación

(1) Si una Comisión anulare parte o todo de un laudo, cada parte podrá requerir que se someta la diferencia a un nuevo 
para la prestación del servicio de agua potable y alcantarillado celebrado entre las demandantes con la Provincia de Tucumán.

En su laudo de 21 de noviembre de 2000, el tribunal arbitral declaró que tenía jurisdicción para resolver parte de la controversia planteada y así lo hizo seguidamente. Sin embargo, se declaró sin jurisdicción para resolver las pretensiones referidas a las acciones y omisiones de las autoridades de la Provincia de Tucumán. ${ }^{48}$

Recurrido en anulación el laudo, el comité ad hoc designado para estos efectos confirmó la jurisdicción del tribunal arbitral para conocer y pronunciarse sobre los extremos que laudó. Sin embargo, seguidamente consideró que el tribunal arbitral había excedido sus poderes cuando se declaró sin jurisdicción para analizar el mérito de los reclamos basados en las acciones y omisiones de las autoridades de la Provincia de Tucumán. Consecuentemente, el comité ad hoc anuló el laudo en este extremo. ${ }^{49}$

Ante esta situación, las demandantes procedieron a iniciar un nuevo arbitraje, el cual se refirió exclusivamente a las reclamaciones contra las acciones y omisiones de las autoridades de la Provincia de Tucumán, que las recurrentes imputaban que eran de responsabilidad de la República Argentina al amparo del BIT Argentina-Francia.

El nuevo tribunal arbitral expidió laudo el 20 de agosto de 2007, encontrando responsable al Estado demandado. ${ }^{50}$

De esta manera, y a diferencia de lo que puede suceder con los laudos arbitrales que se encuentran regulados por una legislación nacional ${ }^{51}$, los

Tribunal. Dicha solicitud deberá serle presentada por escrito al secretario general, y en ella se deberá:

(a) identificar el laudo de que se trata;

(b) indicar la fecha de la solicitud;

(c) explicar en detalle qué aspecto de la diferencia ha de someterse al Tribunal; $e$

(d) ir acompañada del derecho de registro de la solicitud

(...)

(3) Si se hubiere anulado el laudo original solo en parte, el nuevo Tribunal no reconsiderard parte alguna del laudo que no hubiere sido anulada. Sin embargo, podrá, de conformidad con el procedimiento establecido en la Regla 54, suspender o mantener la suspensión de la ejecución de la parte no anulada del laudo hasta la fecha en que dicte su propio laudo".

48 El laudo se ubica en: http://icsid.worldbank.org/ICSID/FrontServlet?requestType=CasesRH\&actionVal=showDoc\&d ocld=DC548_Sp\&caseld=C159.

49 La decisión del comité ad hoc se ubica en: http://icsid.worldbank.org/ICSID/FrontServlet?requestType=CasesRH\&a ctionVal=showDoc\&docid=DC552_Sp\&caseld=C159.

50 Este nuevo laudo se ubica en: http://investmentclaims.com/IIC_307_(2007).pdf.

51 Como anulado que sea un laudo arbitral CIADI, la controversia no se somete al Poder Judicial, sino que se constituye un nuevo tribunal arbitral CIADI que juzgará el caso, se generan así los incentivos correctos para evitar que las partes ínterpongan recursos obstruccionistas o dilatorios. Tal vez sea por esta razón que, como explica Franz KUNDMULLER CAMINITI, "ICSID, 'bella durmiente' despabilada ante la atronadora globalización y el fragor creciente de las controversias en materia de inversión extranjera". En: Revista lberoamericana de Arbitraje, www.servilex.com.pe/ arbitraje/colaboraciones/inversion.htm, p. 16, "[h]asta el año 2002 hubo solamente nueve solicitudes de anulación de laudos arbitrales, para un universo total de 93 casos, en un período de 36 años".

A la fecha de este trabajo, son pocos los laudos arbitrales contra los que se ha iniciado un proceso de anulación, destacando: Amco Asia Corporation, Pan American Development Ltd. y P.T. Amco Indonesia vs. República de Indonesia (Caso ARB/81/1) y Klockner Industrie-Anlagen GmbH, Klockner Belge S.A. y Klockner Handel-smaatschappij B.V.vs. República del Camerún y Société Camerounaise des Engrais (Caso ARB/81/2), cuyos laudos arbitrales fueron anulados y, luego de que se dictaron nuevos fallos arbitrales, el segundo pedido de anulación fue desestimado en ambos casos; Southern Pacific Properties (Middle East) Limited vs. República de Egipto (Caso ARB/84/3), que se resolvió mediante una transacción antes del fallo final sobre la anulación; Maritime International Nominees Establishment vs. República de Guinea (Caso AR8/84/4), Wena Hotels Limited vs. República Árabe de Egipto (Caso ARB/98/4), Philippe Gruslin vs. Malasia (Caso ARB/99/3), Compañía de Aguas del Aconquija S.A. y Vivendi Universal vs. República de Argentina (Caso ARB/97/3), Patrick Mitchell vs. República Democrática de Congo (Caso ARB/99/7), Consortium R.F.C.C. vs. Reino de Marruecos (Caso ARB/00/6), MTD Equity Sdn. Bhd. y MTD Chile S.A. vs. Chile (Caso 
fallos arbitrales CIADI jamás podrán ser revisados por las Cortes de los Estados miembros. ${ }^{52}$

\section{Las causales de anulación}

Las únicas causales de anulación de los laudos arbitrales CIADI son las siguientes ${ }^{53}$ : a) Que el tribunal arbitral se hubiere constituido incorrectamente.

Esta causal resulta procedente cuando, por ejemplo, alguno de los árbitros no cumple con el requisito de nacionalidad, no cuenta con las calificaciones que exige el CIADI o tiene algún conflicto de intereses.

ARB/01/7), CMS Gas Transmission Company vs. República Argentina (Caso ARB/01/8), Repsol YPF Ecuador S.A. vs. Empresa Estatal Petróleos del Ecuador (Petroecuador) (Caso ARB/01/10), CDC Group plc vs. República de Seychelles (Caso ARB/02/14), Hussein Nuaman Soufraki vs. Emiratos Árabes Unidos (Caso ARB/02/7), Empresas Lucchetti, S.A.y Lucchetti Perú, S.A. vs. República del Perú (Caso ARB/03/4) y Joy Mining Machinery Limited vs. República Árabe de Egipto (Caso ARB/03/11). Este último caso se resolvió mediante una transacción antes del fallo final sobre la anulación.

Si bien es cierto que solo en algunos pocos casos los laudos arbitrales han sido anulados, los dos primeros (Amco y Klockner) fueron duramente criticados, al extremo de afirmarse que el sistema de anulación de laudos arbitrales $\mathrm{CIADI}$ se encontraba fuera de control. Sin embargo, recientes fallos sobre esta materia parecen que están poniendo las cosas en su lugar. GAILLARD, Emmanuel, ICSID Annulment. En: Transnational Dispute Management, Vol. 2, No. 2, 2005, p. 38. "The Amco and Klockner cases were severely criticised for being a disguised appeal and what is important to note is that no such criticism was addressed to the recent generation of cases. The WENA and Vivendi cases, despite the partial annulment in Vivendi and the 2002 vintage is the current state of the law". SACERDOTI, Giorgio, Investment Arbitration under ICSID and UNCITRAL Rules: Prerequisites, Applicable Law, Review of Awards, Ob. Cit., p. 45. "Subsequent decisions have shown more self restraint and have focused on the specificity of ICSID arbitration and of BITS provisions, stimulating reflections on the function of the mechanism and of its features". SCHREUER, Christoph, The ICSID Convention: A Commentary, Ob. Cit., p. 893. "Despite this self-professed restraint, the decisions on annulment in Klockner l and Amco / have been criticized severely for crossing the line between annulment and appeal by re-examining aspects of the cases before them that lay outside the narrow confines of annulment". Sobre el particular, leer a: REISMAN, W. Michael, Systems of Control in International Adjudication \& Arbitration -Breakdown and Repair-, Ob. Cit., pp. 50 y 55 .; POSIN, Daniel Q., Recent Developments in ICSID Annulment Procedures, Ob. Cit., p. 171; y SCHREUER, Christoph, The ICSID Convention: A Commentary, Ob. Cit., pp. 897-903.

52 Sobre el tema, leer a: FELDMAN, Mark B., The Annulment Proceedings and the Finality of ICSID Arbitral Awards, Ob. Cit., pp. 85 y ss.; y United Nations Conference on Trade and Development, Course on Dispute Settlement - International Centre for Settlement of Investment Disputes", Ob. Cit., 2.8, pp. 31-32.

53 En la decisión sobre anulación del comité ad hoc; en los seguidos por CDC Group pic vs. República de Seychelles (Caso ARB/02/14), de 29 de junio de 2005, se afirmó que las comisiones ad hoc tienen discrecionalidad para decidir si aun cuando identifican alguna causal de anulación, corresponde proceder de esa manera según las circunstancias. "37. (...) we note that the ad hoc Committees operating during the last two decades have considered that a Commit tee has discretion to determine not to annul an Award even where a ground for annulment under Article 52(1) is found to exist. The Vivendi Committee, for example, stated that an award should be annulled in whole or in part only if annulment is 'appropriate in the circumstances"'. El comité ad hoc (cita 43) basó su apreciación en una opinión de Schreuer, quien considera que no basta probar la existencia de la causal, sino que, además, hay que considerar si esa causal efectivamente afectó el procedimiento arbitral (análisis sustantivo, antes que formal): "A good example for the movement towards this more balanced approach is the position taken by ad hoc Committees on their obligation or discretion to annul once they have found a ground for annulment. In Klocknerl, the ad hoc Committee had still held that a finding that there existed a ground for annulment would have to automatically lead to the annulment of the award. Subsequent ad hoc Committees have rejected this 'hair trigger' standard in favor of a 'material violation' approach. Wena and Vivendi contain further confirmation of this cautious attitude". El fallo se ubica en: http://ita.law.uvic.ca/documents/ CDSeychelles AnnulmentDecision.pdf. Este es al parecer el temperamento que siguió el comité ad hoc en el caso CMS Gas Transmission Company vs. República Argentina (Caso ARB/01/8) en su decisión de 25 de setiembre de 2007. En efecto, en esta decisión el comité ad hoc identificó la existencia de lo que denominó "a series of errors and defects". Sin embargo, consideró que los mismos no justificaban la anulación del fallo arbitral. La decisión se ubica en: http://icsid.worldbank.org//CSID/FrontServlet?requestType=CasesRH\&actionVal=showDoc\&docld=DC6 87_En\&caseld=C4. 
Sin embargo, esta causal difícilmente se presentará, gracias al sistema de designación de árbitros del CIADI, como a sus reglas sobre recusación. ${ }^{54}$

b) Que el tribunal arbitral se hubiere manifiestamente extralimitado en sus facultades.

La manifiesta extralimitación en las facultades del tribunal arbitral se puede presentar cuando los árbitros no aplican "manifiestamente" la ley aplicable (ver los fallos de las comisiones ad hoc en los casos Amco Asia Corporation, Pan American Development Ltd. y P.T. Amco Indonesia vs. República de Indonesia (Caso ARB/81/1), Klockner Industrie-Anlagen $\mathrm{GmbH}$, Klockner Belge S.A. y Klockner Handel-smaatschappij B.V. vs. República del Camerún y Société Camerounaise des Engrais (Caso ARB/81/2) y Maritime International Nominees Establishment vs. República de
Guinea (Caso ARB/84/4))..$^{55}$ Sin embargo, como correctamente indicó el comité ad hoc en el caso Wena Hotels Ltd. vs. República Árabe de Egipto (Caso ARB/98/4) en su resolución sobre anulación de 5 de febrero de 2002, para que proceda esta causal, la extralimitación de las facultades tiene que ser evidente. En cambio, si deriva de una interpretación, la causal ya no resulta procedente, debido a que la extralimitación no es más "manifiesta". 56

En ese sentido, como correctamente señaló el comité ad hoc en el caso Amco Asia Corporation, Pan American Development Ltd. y P.T. Amco Indonesia vs. República de Indonesia (Caso ARB/81/1) en su decisión de 16 de mayo de 1986, el estándar de análisis debe ser el siguiente: "23. La ley que el Tribunal aplicó será examinada por el Comité, no con el fin de investigar si el Tribunal cometió errores en la

54 SCHREUER, Christoph, The ICSID Convention: A Commentary, Ob. Cit., p. 929. "Improper constitution of the tribunal does not seem ever to have been invoked as a ground for annulment and is unlikely to be invoked in the future. The ICSID Secretariat carefully monitors this stage of the proceedings and procedural irregularities are unlikely".

55 Ibidem, p. 932. "Another instance of excess of powers would be a violation of Art. 42 on applicable law. Non-application of the law agreed by the parties or of the law determined by the residual rule in Art. 42(1) goes against the parties' agreement to arbitrate and may constitute an excess of powers".

56 "IT]he excess of power must be self-evident rather than the product of elaborate interpretations one way or the other. When the latter happens the excess of power is no longer manifest". SCHREUER, Christoph, The ICSID Convention: $A$ Commentary, Ob. Cit., p. 933. "An excess of powers is manifest if it can be discerned with little effort and without deeper analysis". PINSOLLE, Philippe, Jurisdictional Review of /CSID Awards, documento presentado en la Conference on Nationality and Investment Treaty Claims, British Institute of International and Comparative Law, 2005, www.biicl.org/ admin/files/Philippe\%20Pinsolle\%20Presentation.pdf, p. 7. "The term 'manifest' means: 'Clear to sight or mind' (Oxford Dictionary), 'Evident, obvious, apparent, plain. Readily perceived by the eye or the understanding' (Random House Dictionary), 'Obvious to the understanding, evident to the mind, not obscure or hidden, and is synonymous with open, clear, visible, unmistakable, indubitable, indisputable, evident and self-evident. In evidence, that which is clear and requires no proof; that which is notorious' (Black's Law Dictionary)".

Fallo sobre anulación del comité ad hoc en los seguidos por CDC Group plc vs. República de Seychelles (Caso ARB/02/14) de 29 de junio de 2005: "39. Article 52(1)(b) allows for annulment of an award where the Tribunal 'manifestly exceeded its powers.' That is, a tribunal (1) must do something in excess of its powers and (2) that excess must be 'manifest'. It is a dual requirement".

40. Common examples of such 'excesses' are a Tribunal deciding questions not submitted to it or refusing to decide questions properly before it.

41. As interpreted by various Committees, the term 'manifest' means clear or 'self-evident'. Thus, even if a Tribunal exceeds its powers, the excess must be plain on its face for annulment to be an available remedy. Any excess apparent in a Tribunal's conduct, if susceptible of argument 'one way or the other', is not manifest". El fallo se ubica en: http://ita.law.uvic.ca/ documents/CDSeychellesAnnulmentDecision.pdf. Decisión de anulación en el caso Repsol YPF Ecuador S.A. vs. Empresa Estatal Petróleos del Ecuador (Petroecuador) (Caso ARB/01/10) de 8 de enero de 2007: “36. (...) Comúnmente se entiende que un exceso en las facultades es 'manifiesto' cuando es 'evidente por sí solo' de la sola lectura del Laudo, es decir, aún antes de examinar en detalle el contenido del mismo". La decisión se ubica en: http://icsid.worldbank.org/ ICSID/FrontServlet?requestType=CasesRH\&actionVal=showDoc\&docld=DC619_Sp\&caseld=C203. Ver además la decisión de anulación de 5 de junio de 2007, en el caso Hussein Nuaman Soufraki vs. Emiratos Árabes Unidos (Caso ARB/02/7), parágrafo 39 (http://ita.law.uvic.ca/documents/SoufrakiAnnulment.pdf). 
interpretación de los requerimientos de la ley aplicable o en la determinación o evaluación de los hechos relevantes a los que se ha aplicado dicha ley. Dicho escrutinio es un deber propio de un Tribunal de Apelaciones, y el Comité no lo es. El Comité se limitará a determinar si el Tribunal de hecho aplicó la ley que debía aplicar a la controversia. El incumplimiento en la aplicación de dicha ley, a diferencia de una mala interpretación de la ley, constituye un exceso manifiesto en las facultades por parte del Tribunal y una causal de nulidad conforme al Artículo 52(1) (b) del Convenio. El Comité ha considerado esta tarea con cautela, estableciendo la diferencia entre el incumplimiento en la aplicación de la ley correspondiente como causal de anulación y la mala interpretación de la ley aplicable como causal de apelación". ${ }^{57}$

Esta causal también es aplicable cuando los árbitros asumen una jurisdicción que manifiestamente no tienen o se niegan manifiestamente a asumirla cuando efectivamente corresponde hacerlo. El primer supuesto, por ejemplo, se presentó en el primer procedimiento arbitral del caso Klockner IndustrieAnlagen $\mathrm{GmbH}$, Klockner Belge S.A. y Klockner
Handel-smaatschappij B.V. vs. República del Camerún y Société Camerounaise des Engrais (Caso ARB/81/2). Aquí, el comité ad hoc encontró que el tribunal arbitral había asumido jurisdicción respecto de un contrato que contenía una cláusula arbitral de sometimiento a la Cámara de Comercio Internacional (CCI). Sin embargo, el comité ad hoc consideró que el análisis del tribunal arbitral para justificar su competencia era sustentable, razón por la cual finalmente se negó a anular el laudo arbitral en este extremo, ya que la extralimitación de las facultades no fue manifiesta.

El otro supuesto se presentó, por ejemplo, en el caso Compañía de Aguas del Aconquija S.A. y Vivendi Universal vs. República de Argentina (Caso ARB/97/3). Aquí el comité ad hoc, en su resolución de 3 de julio de 2002, parágrafo $86^{58}$, dijo: "Se establece, y ninguna parte lo ha impugnado, que un tribunal del CIADI se extralimita en sus facultades no solo si ejerce una jurisdicción que no le corresponde de conformidad con el acuerdo o tratado pertinente y el Convenio del CIADI, interpretados en conjunto, sino también si omite ejercer una jurisdicción que síle corresponde según los mencionados instrumentos jurídicos".59

57 Citado por la decisión del comité ad hoc en el caso Repsol YPF Ecuador S.A. vs. Empresa Estatal Petróleos del Ecuador (Petroecuador) (Caso ARB/01/10), parágrafo 40. En ese mismo sentido, el comité ad hoc en el caso Maritime International Nominees Establishment vs. República de Guinea (Caso ARB/84/4), señaló sobre este particular, lo siguiente: " $[A]$ tribunal's disregard of the agreed rules of law World constitute a derogation from the terms of referente within which the tribunal has been authorized to function. Examples of such a derogation include the application of rules of law other than the ones agreed by the parties, or a decision not based on any law unless the parties had agreed on a decision ex aequo et bono. If the derogation is manifest, it entails a manifest excess of power. Disregard of the applicable rules of law must be distinguished from erroneous application of those rules which, even if manifestly unwarranted, furnishes no ground for annulment". La decisión se ubica en: ICSID Reports, Vol. 4.

58 La decisión se ubica en: http://icsid.worldbank.org/ICSID/FrontServlet?requestType=CasesRH\&actionVal=showDoc \&docld=DC552_Sp\&caseld=C159.

59 United Nations Conference on Trade and Development, Course on Dispute Settlement - International Centre for Settlement of Investment Disputes, Ob. Cit., 2.8, p. 18, "Failure to exercise jurisdiction where jurisdiction does, in fact, exist also constitutes an excess of powers. A decision by a tribunal that states that it lacks competence is rendered in the form of an award. Such an award may be the subject of annulment proceedings". Comité ad hoc en el caso Wena Hotels Ltd. vs. República Árabe de Egipto (Caso ARB/98/4) en su resolución sobre anulación de 5 de febrero de 2002: "Failure to exercise jurisdiction where jurisdiction does, in fact, exist also constitutes an excess of powers. It is not within the tribunal's powers to refuse to decide a dispute or part of a dispute that meets all jurisdictional requirements of Art. 25". PINSOLLE, Philippe, Jurisdictional Review of ICSID Awards, Ob. Cit., p. 10. "The same applies where an arbitral Tribunal refuses to exercise jurisdiction that it possesses. In this case, both parties have consented to arbitration for the dispute in question and are nevertheless deprived of the neutral forum to which they agreed. The expectation of the parties must be respected. In other words, when consent to arbitration is found to exist there is no way out for the arbitral tribunal. Refusing to give effect to this consent amounts to modifying the agreement between the parties. It amounts to denying them what they wanted. Wrongly refusing to exercise jurisdiction when it exists would necessarily entail committing a manifest excess of powers". 
Este es también uno de los argumentos que fue esgrimido en el caso Empresas Lucchetti, S.A. y Lucchetti Peru, S.A. vs. República del Perú (Caso $A R B / 03 / 4)$. En efecto, en este caso el tribunal arbitral, en su decisión sobre jurisdicción de 7 de febrero de 2005, se declaró incompetente para conocer el fondo de la controversia, debido a que el BIT Perú-Chile no habría estado vigente al momento en que sucedieron los hechos en los que se apoyaron las empresas para alegar una supuesta expropiación de sus intereses. ${ }^{60}$ Ante esta situación, las empresas demandantes iniciaron una acción de anulación del laudo arbitral, alegando, entre otros, que los árbitros se habrían manifiestamente extralimitado en sus facultades, al negarse a aceptar su jurisdicción.

Sin embargo, en su decisión sobre anulación de 5 de setiembre de 2007, el comité ad hoc, en mayoría, desestimó este y los demás argumentos de la demandante. ${ }^{61}$

Por último, este caso nos permite aclarar el tema referido al tipo de decisiones que pueden ser sometidas a conocimiento de un comité ad hoc.
En efecto, el artículo 52(1) del Convenio CIADI establece que solo se puede solicitar la anulación "del laudo". Sin embargo, en el caso Lucchetti los árbitros, formalmente hablando, no resolvieron el fondo de la controversia $y$, aun así, las empresas demandantes interpusieron anulación contra esa decisión.

Esto es así porque el Convenio CIADI expresamente establece que si un tribunal arbitral decide como cuestión previa que no tiene jurisdicción ${ }^{62}$, esa decisión será dictada en la forma de un laudo arbitral y, por lo tanto, podrá ser recurrida directamente en anulación. ${ }^{63}$

En cambio, si el tribunal arbitral como cuestión previa o en el laudo final declara que tiene jurisdicción ${ }^{64}$, esta decisión, conjuntamente con el laudo final sobre el fondo, podrá ser recurrida en anulación. ${ }^{65}$

c) Que hubiere habido corrupción de algún miembro del tribunal arbitral.

60 La decisión se ubica en: http://icsid.worldbank.org/ICSID/FrontServlet?requestType=CasesRH\&actionVal=showDo c\&docld=DC686_Sp\&caseld=C225. DI ROSA, Paolo, La jurisdicción ratione temporis en arbitrajes bajo los Tratados Bilaterales de Inversiones. En: Revista Peruana de Arbitraje, No. 2, Lima, 2006, p. 302. “Perú arguyó que el Tribunal carecia de jurisdicción debido a que la controversia se habia definido claramente con anterioridad a la entrada en vigencia del $T B l$, constituyendo los hechos posteriores una simple continuación de la controversia anterior. Los reclamantes, por su parte, sostuvieron que se trataba de dos controversias distintas, que la anterior se habia resuelto en 1998 con las decisiones de los tribunales peruanos que habian fallado a su favor, y que solo era la segunda controversia, la cual habia surgido después de la entrada en vigencia del TBI, la que estaba ante el tribunal CIADI. Ante estas posiciones encontradas, el Tribunal concluyó que (...) el objeto de la controversia anterior no difería de las medidas adoptadas por la municipalidad en 2001 (...) en ese sentido las controversias tuvieron el mismo origen o fuente (...). Con fundamento en estos antecedentes, el tribunal decidió que 'en 1998 la presente controversia estaba formalizada' y que, como resultado de ello, 'la empresa se encuentra en la misma situación en que estaría si no hubiera sancionado el Convenio Bilateral [TBI]". Ver también el análisis que el autor realiza respecto al tema de los "actos continuos o serie de actos del Estado" (pp. 319-326).

61 La decisión se ubica en: http://icsid.worldbank.org/ICSID/FrontServlet?requestType=CasesRH\&actionVal=showDo $c \& d o c l d=D C 683 \_$Sp\&caseld $=C 225$.

62 Artículo 41 del Convenio CIADI.- "(1) El Tribunal resolverá sobre su propia competencia.

(2) Toda alegación de una parte que la diferencia cae fuera de los límites de la jurisdicción del Centro, o que por otras razones el Tribunal no es competente para oírla, se considerará por el Tribunal, el que determinará si ha de resolverla como cuestión previa o conjuntamente con el fondo de la cuestión".

63 Regla 41(6) de las Reglas de Arbitraje.- "(6) Si el Tribunal decidiere que la diferencia no cae dentro de la jurisdicción del Centro, o que no es de su competencia, o que todas las reclamaciones carecen manifiestamente de mérito juridico, dictará un laudo a tal efecto".

64 Si los árbitros se pronuncian como cuestión previa declarando que tienen jurisdicción, no estaremos ante un "laudo", sino simplemente ante una "decisión sobre jurisdicción".

65 SCHREUER, Christoph, The ICSID Convention: A Commentary, Ob. Cit., p. 912. "Preliminary decisions on jurisdiction are 
Hasta donde tenemos conocimiento, nunca se ha planteado esta causal. ${ }^{66}$

d) Que hubiere quebrantamiento grave de una norma de procedimiento.

Lo primero que tenemos que decir sobre este particular es que, para que proceda plantear esta causal, la parte que afirma haber sido perjudicada tiene que haber reclamado en su momento, sin que se corrigiera la supuesta violación. ${ }^{67}$

En segundo lugar, nosotros consideramos que el estándar de análisis de esta causal ha sido correctamente fijado por el comité ad hoc que conoció de la anulación en el caso Wena Hotels Ltd. vs. República Árabe de Egipto (Caso ARB/98/4), en su decisión de 5 de febrero de 2002: "The said provision refers to a set of minimal standards of procedure to be respected as a matter of international law. It is fundamental, as a matter of procedure, that each party is given the right to be heard before an independent and impartial tribunal. This includes the right to state its claim or its defense and to produce all arguments and evidence in support of it. This fundamental right has to be ensured on an equal level, in a way that allows each party to respond adequately to the arguments and evidence presented by the other (...)

In order to be a 'serious' departure from a fundamental rule of procedure, the violation of such a rule must have caused the Tribunal to reach a result substantially different from what it would have awarded had such a rule been observed. In the words of the ad hoc Committee's Decision in the matter of MINE 'the departure must be substantial and be such as to deprive a party of the benefit or protection which the rule was intended to provide" 68

subsequently incorporated into awards (...) At that stage they become subject to annulment as parts of awards.

If the tribunal decides that the dispute is not within the Centre's jurisdiction or outside its competence (...) it will render an award to this effect (...) Such an award is, by definition, final and subject to annulment". Por ejemplo, en el primer caso arbitral seguido por Amco Asia Corporation, Pan American Development Ltd. y P.T. Amco Indonesia vs. República de indonesia (Caso ARB/81/1), se recurrió en anulación contra el laudo arbitral final (de 16 de mayo de 1986) y contra la decisión sobre jurisdicción (25 de setiembre de 1983).

66 Ibidem, p. 967."It strikes at the root of the integrity of the arbitrai process. Instances of corruption of members of arbitral tribunals seem to be so unusual that they are hardly ever contemplated".

67 Ibidem, p. 911. "I]t would appear unacceptable to let a party that has knowingly failed to challenge a serious irregularity before the tribunal later attack the award in annulment proceedings". Obviamente estas palabras son plenamente aplicables a las causales a) y b) estudiadas.

Justamente sobre este particular, la regla 27 de las Reglas de Arbitraje, dispone: "Si una parte que sabiendo, o debiendo haber sabido, que no se ha observado alguna disposición del Reglamento Administrativo y Financiero, de estas Reglas o de cualquier otra regla o algún acuerdo aplicable al procedimiento, o alguna resolución del Tribunal, y no objeta con prontitud dicho incumplimiento, se considerará, salvo respecto de lo dispuesto en el Artículo 45 del Convenio, que ha renunciado a su derecho a objetar". SCHREUER, Christoph, The ICSID Convention: A Commentary, Ob. Cit., p. 983. "Ad hoc committees have held that a party that has failed to object to a violation of procedure before the tribunal may not rely on this violation as a ground for annulment. In Klocknerl, the ad hoc Committee remarked in the context of an alleged violation of Art. 25(1)(d) that an application for annulment (...) [cannot] be used by one party to complete or develop an argument which it could and should hove made during the arbitral proceedings. More specifically, in the context of an alleged violation of the right to be heard (...) the ad hoc Committee said:

(...) it suffices to note that the Claimant has not established that it made a timely protest against the serious procedural irregularities it now complains of. Subject to what will be valid later, Rule 26 [now Rule 27] of the ICSID Rules of Procedure for Arbitration Proceedings would therefore rule out a good part of its complaints".

68 United Nations Conference on Trade and Development, Course on Dispute Settiement - International Centre for Settiement of Investment Disputes, Ob. Cit., 2.8, pp. 22-23. "To be serious the departure must be substantial rather than minimal. The departure must have had a material effect on the affected party. It must have deprived that party of the benefit of the rule in question. For instance, if a party is deprived of its rights to be heard, the departure is not serious if it is clear from the circumstances that the party never intended to exercise the right (...) A party must react immediately to a violation of proper procedure by stating its objection and by demanding compliance. Arbitration Rule 27 states that failure to object will be interpreted as a waiver to object at a later stage". 
Justamente porque, para que proceda esta causal, se tiene que haber quebrantado seriamente una norma fundamental del procedimiento $0^{69} \mathrm{y}$, además, tiene que probarse que esta situación ha llevado a que el tribunal arbitral en términos sustantivos haya llegado a un resultado distinto al que hubiera arribado de no haberse cometido la violación ${ }^{70}$, nosotros entendemos que si bien esta causal ha sido alegada en varias oportunidades, hasta el momento no ha sido amparada. $^{71}$

e) Que no consten en el laudo arbitral los motivos en que se funda.

Como bien señaló el comité ad hoc en su fallo sobre anulación de 5 de febrero de 2002, en los seguidos por Wena Hotels Ltd. vs. República Árabe de Egipto (Caso ARB/98/4), esta causal no autoriza a que se revise el fondo de la con- troversia o a que se reconsidere la decisión del tribunal arbitral, ya que está referida únicamente al requerimiento de que el tribunal arbitral explique los hechos y el derecho en que basa su decisión. ${ }^{22}$

Además, la obligación del tribunal arbitral de sustentar su decisión no los obliga a analizar todos y cada uno de los argumentos presentados por las partes, sino únicamente aquellos que son cruciales o esenciales para la resolución de la controversia. ${ }^{73}$

En ese sentido se pronunció el comité ad hoc en el caso Compañía de Aguas del Aconquija S.A. y Vivendi Universal vs. República de Argentina (Caso ARB/97/3), en su decisión de 3 de julio de 2002:"64. Una fuente de preocupación de mayor envergadura es el fundamento de la omisión de 'expresar los motivos', ya que no

69 SCHREUER, Christoph, The ICSID Convention: A Commentary, Ob. Cit., pp. 970-971. El autor cita el fallo del comité ad hoc de 22 de diciembre de 1989, en los seguidos por Maritime International Nominees Establishment vs. República de Guinea (Caso ARB/84/4): "5.05 A first comment on this provision concerns the term 'serious'. In order to constitute a ground for annulment the departure from a 'fundamental rule of procedure' must be serious. The Committee considers that this establishes both quantitative and qualitative criteria: the departure must be substantial and be such as to deprive a party of the benefit or protection which the rule was intended to provide (...)

5.06 A second comment concerns the term 'fundamental'; even a serious departure from a rule of procedure will not give rise to annulment, unless that rule is 'fundamental.' The Committee considers that a clear example of such a fundamental rule is to be found in Article 18 of the UNCITRAL Model Law on International Commercial Arbitration (...)

The term 'fundamental rule of procedure' is not to be understood as necessarily including all of the Arbitration Rules adopted by the Centre".

70 Fallo sobre anulación del comité ad hoc en los seguidos por CDC Group plc vs. República de Seychelles (Caso ARB/02/14) de 29 de junio de 2005: "48. (...) here the departure must be serious and it must be from a fundamental rule of procedure. It is a dual requirement. Not just any departure from any rule of procedure will support annulment.

49. A departure is serious where it is 'substantial and [is] such as to deprive the party of the benefit or protection which the rule was intended to provide.' In other words, 'the violation of such a rule must have caused the Tribunal to reach a result substantially different from what it would have awarded had the rule been observed". La decision se ubica en: http:// ita.law.uvic.ca/documents/CDSeychellesAnnulmentDecision.pdf.

71 SCHREUER, Christoph, The ICSID Convention: A Commentary, Ob. Cit., pp. 972-982.

72 "The ground for annulment of Article 52(1)(e) does not allow any review of the challenged Award which would lead the ad hoc Committee to reconsider whether the reasons underlying the Tribunal's decisions were appropriate or not, convincing or not. As stated by the ad hoc Committee in MINE, this ground for annulment refers to a 'minimum requirement' only. This requirement is based on the Tribunal's duty to identify, and to let the parties know, the factual and legal premises leading the Tribunal to its decision. If such sequence of reasons has been given by the Tribunal, there is no room left for a request for annulment under Article 52(1)(e)". Ver también el fallo sobre anulación del comité ad hoc en los seguidos por CDC Group ple vs. República de Seychelles (Caso ARB/02/14) de 29 de junio de 2005, parágrafos 66-72, que hicieron suya la opinión en Wena.

73 United Nations Conference on Trade and Development, Course on Dispute Settlement - International Centre for Settlement of Investment Disputes, Ob. Cit., 2.8, p. 26. "The tribunal's obligation to deal with every question submitted to it does not mean that it has to address every argument advanced by a party. Some arguments may be irrelevant, peripheral orobsolete. In order to form a basis for annulment, a question that has not been dealt with, must be an essential question 
está calificada con un adjetivo como 'manifiest $a^{\prime}$ o 'seria'. Sin embargo, se acepta tanto en los casos como en la literatura que el Artículo 52(1) (e) se refiere a la omisión de expresar motivo alguno respecto de todo o parte de un laudo, no a la falta de expresión de razones correctas o convincentes. Cabe reiterar que un comité ad hoc no es un tribunal de apelaciones. Siemprey cuando las razones que dé un tribunal puedan ser comprendidas y se relacionen con las cuestiones tratadas ante el tribunal, la exactitud de las mismas no es pertinente. Más aún, los motivos pueden manifestarse en forma sucinta o con todo detalle, y las diferencias tradicionales judiciales difieren en su manera de expresar las razones. Debe permitirse a los tribunales cierta discrecionalidad en cuanto al modo en que expresan sus razones.

65. En la opinión del Comité, la anulación con- forme al Artículo 52(1)(e) sólo debe ocurrir en un caso muy manifiesto. En opinión del Comité, es necesario que se satisfagan dos requisitos: en primer término, que la omisión de expresar los motivos en que se fundó el Laudo debe suponer que la decisión sobre una cuestión en particular carece de cualquier justificación expresa y, en segundo término, que esa cuestión debe ser en si misma necesaria para la decisión del tribunal. Suele decirse que las razones contradictorias se cancelan reciprocamente, y asi debe suceder si son genuinamente contradictorias. Pero en ocasiones los tribunales deben compensar consideraciones conflictivas una con otras, y un comité ad hoc debe tener mucho cuidado en no discernir que hay una contradicción cuando lo que en efecto se expresa en los fundamentos de un tribunal, según podría decirse con mayor exactitud, no es sino el reflejo de tales consideraciones conflictivas".

in the sense that it could have affected the outcome of the award. An essential question may also be understood in the sense of a crucial or decisive argument. An argument is crucial or decisive if its acceptance would have altered the tribunal's conclusions". Sobre este particular, leer a: SEDLAK, David R., ICSID'S Resurgence in International Investment Arbitration: Can the Momentum Hold". En: Penn State International Law Review, Vol. 23, 2004, p. 163; y STURZENEGGER, Marc, ICSID Arbitration and Annulment for Failure to State Reasons: The Decision of the Ad Hoc Committee in Maritime International Nominees Establishment v. The Republic of Guinea. En: Journal of International Arbitration, Vol. 9, No. 4, 1992, pp. 173-198.

Justamente sobre este particular, ver la decisión sobre anulación del comité ad hoc en los seguidos por Patrick Mitchell vs. República Democrática del Congo (Caso ARB/99/7) de 1 de noviembre de 2006, que consideró que el razonamiento del tribunal arbitral había sido incompleto y oscuro respecto al requisito de que exista una inversión y dispuso anular el laudo arbitral por este motivo, al considerarlo grave. 